\title{
Experimentación geométrica y constructiva en piedra: algunos casos especiales de escaleras de caracol
}

\section{Geometrical and construction experimentation in stone: some uncommon examples of spiral staircases}

\author{
A. Sanjurjo ${ }^{*}$
}

RESUMEN

La literatura técnica de la cantería describió, fundamentalmente entre el siglo XVI y el XVIII, complejos caracoles de piedra que, en algunos casos, no se llevaron nunca a la práctica. Asimismo, escondidos en torreones y disimulados en machones, estribos y contrafuertes encontramos ejemplos construidos, con soluciones distintas a las de los tratados escritos, de un gran virtuosismo técnico, testigos evidentes de procesos de experimentación y capacitación profesional. Su compleja geometría y difícil construcción las caracteriza, y acentúa aún más su singularidad en contraposición con su pequeña dimensión y su secundaria ubicación. Ambos modelos, los pensados y dibujados en los tratados, pero no construidos, y los construidos en iglesias y catedrales, pero no contemplados en los tratados, son el objeto de este artículo. En él, hacemos un recorrido por algunas de esas escaleras especiales, estudiándolas y tratando de encontrar el porqué de su existencia.

970-5

Palabras clave: Escalera; caracol; estereotomía; tratado.

\section{SUMMARY}

Stonecutting specialized literature often describes, specifically between the 16th and the 18th century, complex spiral staircases that, in many cases, have never been carried out practically. At the same time, hidden inside of towers and turrets or concealed in buttresses, there is a variety of built examples whose arrangements differentiate from those of the written treatises, showing an outstanding technical mastery, clear sign of experimentation and professional training. They are characterized by their complex geometry and complicated construction, which emphasizes their singularity in comparison to their small dimension and their irrelevant location. Both models, those conceived and drawn in the treatises, but not built, and those constructed in churches and cathedrals, but not considered in the treatises, are the objective of this paper. To this end, we will look at some of these stairs, analysing them and trying to find the source of their existence.

Keywords: Staircase; spiral; stereotomy; treatise. 
Las escaleras de caracol están presentes en la construcción en piedra desde la Antigüedad. Hoy sabemos que ya fueron empleadas tanto en la arquitectura griega como en la romana y que a partir de los primeros siglos de nuestra era se comenzaron a utilizar de manera más o menos frecuente en construcciones civiles y religiosas (1). Su función ha sido, desde ese momento, casi exclusivamente de servicio, renunciando al protagonismo de la composición en la planta de los edificios en la que destacan otros tipos de escaleras. Por esa razón su ubicación y a veces su propia existencia han permanecido casi inadvertidas para muchos.

En la arquitectura romana las escaleras de caracol se encontraban, por lo general, disimuladas entre los gruesos muros de fábrica. Esto contribuía a que pasaran desapercibidas desde el punto de vista de la volumetría general, al no poderse identificar desde el exterior o el interior de los edificios (2, p. 46-48).

Con el desarrollo de la arquitectura carolingia se produce un cambio de concepción en las escaleras de traza circular, que comienzan a localizarse, con frecuencia, en torres y torrecillas, diseñadas ex profeso para tal fin. Estas torres actuarán como factor de conformación de la percepción volumétrica de los edificios (2, p. 46).

A partir de este momento empieza a surgir, en las partes altas de los edificios religiosos, un elemental sistema de circulación en el que las escaleras van a jugar un papel fundamental y que culminará con los complejos sistemas de circulación de servicio de las grandes construcciones góticas.

Estas dos concepciones antagónicas en el diseño de los caracoles pervivirán a lo largo de la historia de la arquitectura. La primera tratará de delimitar al máximo el impacto formal de estas escaleras, disimulándolas dentro de gruesos muros de fábrica u otro tipo de elementos constructivos, como principalmente se hizo en la arquitectura romana. La segunda idea, basada en la disposición exterior de este tipo de elementos, se caracterizará por la aparición de torres y torretas en las fachadas, el transepto o la cabecera de las iglesias.

Dentro de la tradición de disimular los caracoles se inicia una práctica que consiste en sustituir un machón de fábrica o un elemento constructivo por una escalera de caracol, normalmente de servicio y mantenimiento de las cubiertas.
Spiral staircases are present in stone construction since Antiquity. Today we know that they were already employed in Greek and in Roman Architecture, and that since the first centuries of our Era they were used more or less frequently in civil and religious constructions (1). Later on, in most cases the service use of these stairs has get over their relevance in the composition of the plan of the buildings, in which other type of stairs stand out. For this reason, its location and sometimes its very existence have been nearly unobserved for many people.

In Roman architecture spiral staircases were generally dissimulated between the wall thickness, so that the general volume of the building did not show the very existence of these elements, being impossible to be identified neither from the outside nor from the interior of the building. (2, p. 46-48)

The development of the Carolingian architecture will bring a change in the conception of the stairs on circular plan. They were frequently located in towers and turrets, designed especially to that purpose. These towers will gain importance and act as a factor of conformation of the volumetric perception of the buildings (2, p. 46).

From that moment on, an elemental circulation system will appear in the higher parts of the religious buildings in which the stair will play a fundamental role. Its development will culminate in the more complex service circulation systems of the great Gothic constructions.

Both antagonistic conceptions of the design of spiral stairs will survive simultaneously in the course of the history of architecture. According to the first one, the formal impact of these stairs should be minimum, being hidden within the thickness of the walls or other construction elements, as it was done principally in Roman architecture. The second idea, based on the exterior location of this type of elements, is characterized by the presence of towers and turrets in the façades, the transept and the choir of the churches.

According to the tradition of disguising the spiral staircases, a practice will start consisting in substituting a buttress or a construction element by a spiral staircase, usually of service and maintenance of the roofs.

Some singular examples of substitution of buttresses and flying buttresses for spiral staircases can be found, such as in 
Encontramos algunos ejemplos curiosos de sustitución de contrafuertes y arbotantes por escaleras de caracol como el caso de la catedral de Bourges y de Senlis, donde, para acceder al bajo cubierta general del edificio, se ubican sendas escaleras en el interior de los contrafuertes que se rematan con unas escaleras exteriores de un solo tramo que recorren la cara superior del arbotante en busca del espacio interior (3, p.131) (Figura 1). Soluciones parecidas podríamos encontrar en las construcciones góticas de buena parte de Europa, como el caracol de subida al octógono de la catedral de Ely, inserto en uno de los contrafuertes de la torre del crucero, o los caracoles abovedados en los estribos de la fachada norte en la cabecera de la iglesia de Saint Etienne de Beauvais, posiblemente ejecutados por los Chambiges ya en el siglo XVI (Figura 2).

La sustitución de elementos estructurales por escaleras de caracol tiene su origen en una concepción según la cual estas se podían considerar también como elementos macizos y por tanto también estructurales, según se desprende del informe de Francisco de Colonia sobre el estado de la catedral de Segovia (4, p.230)(5, p. 290)

Iten me paresçe que los dos husillos que estan elegidos y subidos a la parte de las colaterales en la pared de los pies se deven acabar conmo mejor van con algun buen remate que sea para adorno a manera de torrezeta o conmo mejor parezca y ansi cada caracol de aquellos bastara
Bourges' and Senlis' cathedrals, where, to have access to the general roof of the building, two stairs are located inside the buttresses, being crowned by one flight exterior stairs that cover the upper surface of the flying buttresses turning inwards (3, p. 131) (Figure 1). Similar solutions are to be found in the Gothic constructions great part of Europe, as in the spiral staircase that gives access to the octagon in Ely's Cathedral inside of one of the buttresses of the tower of the crossing, or the vaulted spiral staircases in the buttresses of the north façade in the choir of the church of Saint Etienne in Beauvais, possibly carried out by the Chambiges in the $16^{\text {th }}$ century (Figure 2).

The replacement of structural elements with spiral staircases has its origin in a conception according to which these could be considered as solid elements and thus also structural ones, as it can be deduced from the report of Francisco de Colonia about the state of Segovia's Cathedral (4, p. 230)(5, p. 290)

Iten me paresçe que los dos husillos que estan elegidos y subidos a la parte de las colaterales ne la pared de los pies se deven acabar conmo mejor van con algun buen remate que sea para adorno a manera de torrezeta o conmo mejor parezca y ansi cada caracol de aquellos bastara para estribos en aquella parte porque los huecos de los caracoles siempre se cuentan por maçiço.

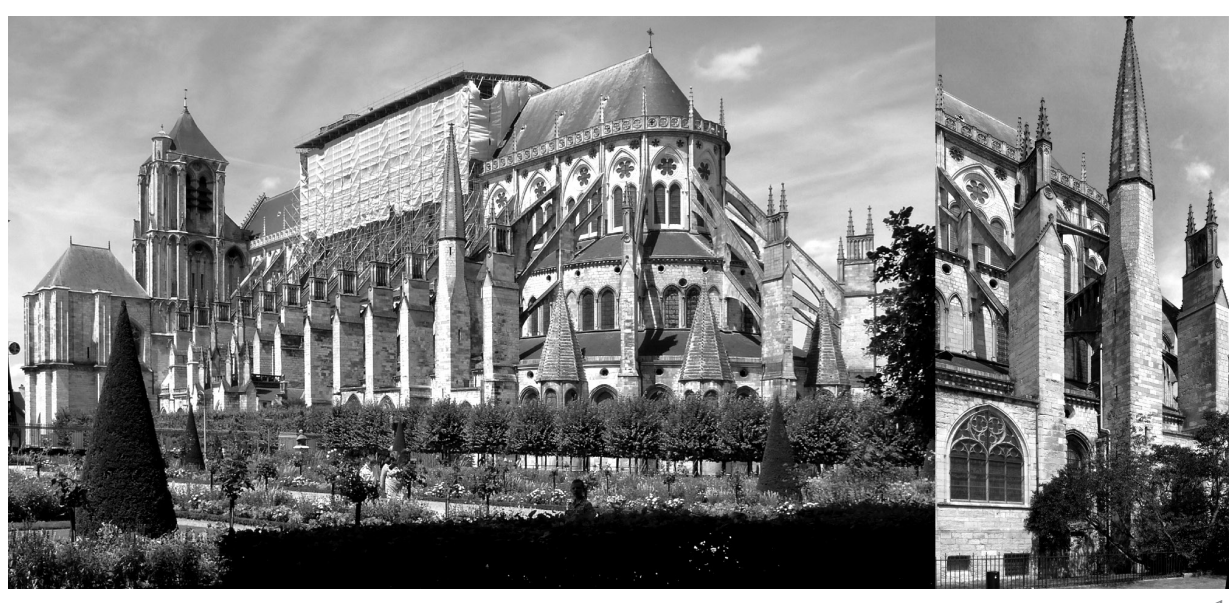

para estribos en aquella parte porque los huecos de los caracoles siempre se cuentan por maçiço.

El periodo gótico inicial se caracteriza por la utilización casi generalizada de los caracoles de husillo. Estos están realizados a partir de una pieza monolítica, más o menos compleja en su talla, que incorpora
1. Catedral de Bourges. Escalera de caracol inserta en uno de los contrafuertes de la fachada sur en su encuentro con la cabecera.

1. Bourges Cathedral. Spiral staircase inside of the buttress in the south façade, close to the choir.

2. Planta de la Iglesia de Saint Etienne de Beauvais. En la fachada norte se pueden apreciar las cajas de dos caracoles que sustituyen a los contrafuertes estructurales.

2. Plan of the church of Saint Etienne de Beauvais. In the north façade two stairwells substitute both structural buttresses. 
la parte proporcional de tambor del nabo central. La escalera se construye al mismo tiempo que la fábrica que recorre, por lo que tiene una doble misión, durante la construcción y, posteriormente, de mantenimiento. Al construirse solidariamente con la fábrica que la envuelve, nos puede aportar importante información sobre el estado de los trabajos en cada momento. Las marcas de cantería, así como las dimensiones y enjarjes de las fábricas, nos pueden ayudar a determinar la autoría, la cronología o los avances de la obra general $(5,290)$.

En el foco mediterráneo encontramos, al mismo tiempo, algunas realizaciones sobresalientes vinculadas probablemente a las casas reales. Nos referimos al caracol de la torre norte del transepto de la catedral de Barcelona ubicado en el encuentro entre ésta y el Palacio Real, adyacente (s. XIII), y a la escalera de la torre este del Castillo de Maniace en Siracusa (Sicilia), que sirvió de acceso a las dependencias del Rey (s. XIV). Tienen características comunes que han sido ya descritas (6). Se los podría denominar como husillos abovedados, pues el machón que soporta el peldañeado tiene un diámetro de reducidas dimensiones y en una sola pieza se resuelve una porción de machón, el arranque de la bóveda helicoidal y la primera parte del peldaño. Están emparentadas de alguna manera con la vis de Saint Gilles ${ }^{1}$, aunque la solución técnica de diseño y corte de la piedra es bastante diferente.

1 La vis de Saint Gilles es uno de los modelos presentes en la mayor parte de tratados dedicados al estudio de la estereotomía en Francia. Debe su nombre a un pequeño fragmento de escalera de caracol cubierta por una bóveda helicoidal en piedra que se conserva en lo que fue el transepto de la iglesia de la Abadía de Saint Gilles. Su datación no está clara, pero probablemente fue ejecutada en el siglo XII. Este modelo, como otros comunes en la praxis del arte de la piedra, traspasó la frontera Ilegando a España con el nombre de via de San Gil. Varios manuscritos hispanos elaborados entre el siglo XVI y XVIII recogen este modelo y tratan de explicarlo.

The vis de Saint Gilles is one of the models present in many treatises devoted to the study of the stereotomy in France. Its name is due to a small fragment of spiral staircase on circular plan, covered by a helicoidal stone vault that is preserved in the former transept of the church of Saint Gilles Abbey. Its date is not clear, but it was probably built in the 12th century. This prototype, as well as other common in the praxis of stonecutting, was transferred to Spain as vía de San Gil. Many Spanish manuscripts developed between the 16th and the 18th centuries include it and tried to explain it.

la historia de la construcción en piedr la transición entre los hábitos constructivos góticos y la búsqueda por utilizar el nuevo lenguaje del Renacimiento, aparecen algunas realizaciones notables y singulares sobre las que nos detendremos un momento. aparecen principalmente en Castilla, de la mano de importantes maestros, y que vamos a denominar husillos con machón helicoidal, y a un grupo de caracoles abovedados realizados en Andalucía, vinculados a la figura del maestro mayor del obispado de Cádiz Francisco Rodríguez Cumplido (1494-1569), que tienen un antecedente en una singularísima escalera de la catedral de Beauvais ejecutada bajo la dirección de Martin Chambiges. Ninguno de los dos tipos de caracoles citados fueron recogidos en las distintas colecciones de aparejos de cantería que se han conservado hasta la fecha ni en los tratados posteriores dedicados al arte del corte de piedras.
The early Gothic period is characterized by the largely employment of newel spiral staircases. These are developed from a monolithic piece, more or less complex in its carving, that includes the corresponding part of the central buttress cylinder. The construction of the stair coincides in time with that of the masonry covering it, having therefore a double function, during the construction process and, later on, for maintenance. As its construction is bounded with the masonry that covers it, it can be a source of information about the different stages of the construction process. The masons' marks, as well as the dimensions and joints of the masonry can help us determine the authorship, the chronology or the timing of the general works $(5,290)$.

In the Mediterranean area, at the same time, some extraordinary executions in relation to the royal household can be found. We are referring to the spiral staircase inside the north tower of the transept of Barcelona's cathedral, located next to the royal palace $\left(13^{\text {th }}\right.$ century), and to the stair inside the eastern tower of Maniace's Castle in Siracuse (Sicily), that provided access to the royal rooms ( $14^{\text {th }}$ century). Their common characteristics have already been described (6). They could be named as vaulted newel stairs, considering the reduced dimensions of the diameter of the newel that supports the steps. In addition, and in only one piece, a portion of the newel, the springing of the helicoidal vault, and the first part of the step are executed at the same time. This type of stairs is related in some way with the vis de Saint Gilles ${ }^{1}$, although the technical solution of the design and the stone cutting are very different.

Nos referimos a un grupo de escaleras que
In a specially fruitful stage in the history of stone construction, in the transition between the Gothic construction habits and the search for a new language of the Renaissance, some outstanding and singular executions were performed, which will later be comented. It refers to a group of stairs, that we will call spiral stairs with helicoidal newel, present mainly in Castille and developed by important masters, and to a group of vaulted spiral staircases performed in Andalucía, linked to the figure of Francisco Rodríguez Cumplido (1494-1569), master mason of the bishopric of Cádiz. These stairs show a clear influence of the singular stair in Beauvais' cathedral developed under the leadership of Martin Chambiges. None of both types of spiral staircases were gathered in the different stone bondings collections that are preserved to the date in later treatises devoted to the art of stonecutting. 


\section{HUSILLOS CON MACHÓN HELICOIDAL}

Hemos denominado así a un grupo de cinco escaleras de caracol de especial singularidad en su trazado². Están ubicadas en edificios de gran importancia en los que trabajaron maestros y aparejadores de primer nivel. Se trata del caracol del tercer tramo de la torre de la iglesia de Santiago Apóstol en Villa del Prado, donde trabajó el aparejador de El Escorial, Pedro de Tolosa. Encontramos otro ejemplo en los caracoles de subida al púlpito en el refectorio del monasterio de San Lorenzo de El Escorial, y un tercer ejemplo en un caracol de servicio a las cubiertas en la iglesia del antiguo convento jerónimo de Santa Catalina en Talavera de la Reina (Figura 3). En este convento dio trazas para la iglesia Alonso de Covarrubias y posiblemente trabajó también Pedro de Tolosa. Se tiene noticia de la visita del aparejador de El Escorial en 1567, momento en el que la cabecera y crucero se encuentran terminados y se está trabajando en el remate de las cubiertas, lugar donde se ubica este singular caracol. (7, p. 210)

Un cuarto ejemplar se ubica en la catedral de Plasencia, y el quinto en la catedral de Sevilla.

De un primer análisis de estos cinco caracoles podemos deducir que están diseñados de una manera similar, es decir, que pertenecerían a un mismo tipo de escaleras de husillo, pues todas presentan un vástago central evidente. Este machón central no es vertical, como en los husillos convencionales, sino que tiene forma helicoidal. $\mathrm{Si}$ analizamos la longitud de cada pieza de peldaño, nos damos cuenta de que tienen una dimensión mayor que la que le correspondería a un peldaño de un caracol de husillo. El ejemplar ubicado en la torre de la iglesia de Villa del Prado es el que presenta un diseño más tosco. De hecho su intradós no está labrado formando un helicoide, como en el resto de los casos, sino que presenta el escalonamiento habitual de los peldaños. Podría parecer, por consiguiente, un ejercicio resuelto con cierta torpeza o incluso con un error de medidas. Sin embargo, si observamos este tipo de escaleras desde arriba hacia abajo, intentado restituir su planta, nos damos cuenta de que los peldaños no son radiales, es decir, no siguen una dirección hacia el centro del círculo generador de la caja de la escalera, como es habitual en la mayoría de caracoles.

Podría interpretarse como un intento por abrir el espacio en el tiro de la escalera y, por lo tanto, por transformar el machón recto en uno casi helicoidal. Sería casi un

\section{SPIRAL STAIRS WITH CENTRAL HELICOIDAL NEWEL}

The term used, spiral stairs with central helicoidal newel refers to a group of five spiral staircases with a special singularity in their layout ${ }^{2}$. They are located in important buildings where first-level master masons worked. We mean the spiral staircase on the third flight of the tower of the church of Santiago Apóstol in Villa del Prado, where Pedro de Tolosa, the master mason of El Escorial, took part. We find another example in the spiral stair that leads to the pulpit in the refectory of San Lorenzo del El Escorial monastery, and a third example in the spiral stair that gives access to the roof of the church from the ancient jeromes convent of Santa Catalina in Talavera de la Reina (Fig. 3). Alonso de Covarrubias and possibly also Pedro de Tolosa were involved in the design of the church of this convent. We have evidence of the visit of the master mason of El Escorial in 1567, when the choir and the crossing were already completed and the construction works were focused on the completion of the roofs, where this singular spiral staircase is located (7, p. 210).

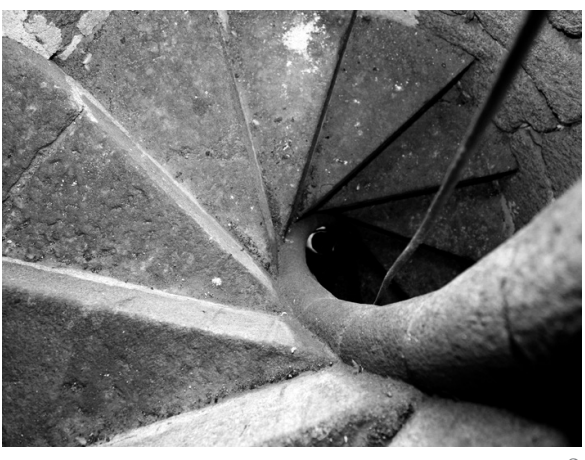

A fourth example is located in the cathedral of Plasencia, and the fifth one in the cathedral of Sevilla.

From a first analysis of these five staircases it can be inferred that they follow a same design pattern, that is to say, that they belong to a group of the same type of spiral staircases with central newel, a clear element present in all of them. This central buttress is not vertical, as in the conventional newel spiral stairs, being in this case helicoidal. If we analyze the length of each step piece, we become aware that they are longer than it would correspond to a step of a newel spiral stair. The example located in the tower of Villa del Prado church is the one that shows the most simple design. In fact, its intrados surface is not carved forming a helicoid, as in the other cases, but presenting the usual staggering of the steps. It could seem, therefore, a rough work o even a dimensional error. But, looking
3. Escalera de caracol de subida a las cubiertas. Iglesia del convento jerónimo de Santa Catalina en Talavera de la Reina (Toledo). Fotografía del autor.

3. Spiral staircase to the roof Church of the jeromes convent of Santa Catalina in Talavera de la Reina (Toledo). Photography by author
2 Debo el conocimiento de algunas de estas escaleras a los profesores Rabasa, Alonso, López Mozo y Pinto Puerto.

${ }^{2}$ We know about these stairs due to Professors Rabasa, Alonso, López Mozo and Pinto Puerto. 
4. Izquierda. Escalera de caracol de subida al órgano de la catedral de Plasencia. Derecha. Escalera de caracol de subida a las cubiertas. Iglesia del convento jerónimo de Santa Catalina en Talavera de la Reina (Toledo). Fotografías del autor

4. Left. Spiral staircase to the organ of the cathedral of Plasencia. Right. Spiral staircase to the roof. Church of the jeromes convent of Santa Catalina in Talavera de la Reina (Toledo). Photographies by author.

${ }^{3}$ A partir del siglo XV aparecen, fundamentalmente en el ámbito mediterráneo, un grupo de escaleras de caracol en las que el machón central se desplaza transformándose en una moldura perimetral y dejando su lugar a un espacio hueco que permite el paso de la luz. En la Lonja de Palma se encuentra la escalera que tradicionalmente se ha considerado como la primera de este tipo, y la que le ha dado su denominación: Caracol de Mallorca. Los tratados manuscritos de cantería elaborados en el ámbito hispano entre los siglos XVI y XVII recogen esta tipología con su denominación. El Caracol de Mallorca constituye uno de los modelos estereotómicos de mayor relevancia en la historia de la construcción pétrea en España.

In the 15th century, appeared, basically in the Mediterranean area, a group of spiral staircases in which the central buttress is transformed into a hole with a perimetral molding, allowing the entry of light through this opening. In the Lonja de Palma we find the stair that has been considered traditionally as the first one of this type, and which has given name to it: Caracol de Mallorca. Stonecutting manuscripts, developed in the Hispanic area between the 16th and the 17th centuries, collect this model with this name. The Caracol de Mallorca is one of the most important stereotomy model in stone construction history in Spain.
Caracol de Mallorca ${ }^{3}$. Pero también es una forma de disponer el peldañeado tangente a un cilindro ideal, en lugar de radial. Posiblemente para poder colocar más peldaños por giro, o que estos sean más cómodos. De esta manera, los peldaños efectivamente tienen una longitud mayor que en el caso de un husillo convencional con el machón cilíndrico vertical. Este tipo de escaleras presenta un alzado muy característico que se repite en todos los casos encontrados (Figura 4). Puede parecer un torpe intento por formar un caracol con ojo, pero no lo es.

Otro ejemplo de este tipo de escaleras lo encontramos en la catedral de Plasencia. Allí, en la subida al órgano o melón, existe un caracol de reducidas dimensiones (177 cm de diámetro), rematado con un cupulín esférico despiezado con una sola hilada helicoidal, que descubrió el profesor Enrique Rabasa. No tenemos certeza de a quién se debe esta escalera (Figura 5). En Plasencia trabajaron, entre otros maestros, Alonso de Covarrubias, quien trazó también la iglesia del convento jerónimo de Talavera de la Reina, y Rodrigo Gil de Hontañón. Hay otro cupulín de este tipo, con despiece helicoidal, en el remate de un caracol de ojo en el Palacio de los Guzmanes en León, obra también de Rodrigo Gil. Como pieza de este rompecabezas de lugares, autores y elementos constructivos encontramos una pequeña cúpula con despiece helicoidal en at this type of stair from above, trying to restore the plan, we realize that the steps are not disposed radially, that is, that they do not follow a direction to the centre of the circumference that generates the stairwell, as it is usual in most cases of spiral stairs.

We could understand this as an attempt to open space in the stairwell and therefore to transform the straight well into a helicoidal one. It would be almost a Caracol de Mallorca ${ }^{3}$. But it is also a way to dispose the steps tangent to an ideal cylinder, instead of radially, possibly, to arrange more number of steps per turning or to achieve more comfortable steps. In this way, the steps have indeed more length than in the case of a conventional newel spiral stair with a vertical cylindrical buttress. This type of stair presents a characteristic elevation that is repeated in all encountered cases (Figure 4). It could seem to be a clumsy attempt to execute a spiral staircase with well, but it is not the case.

We can find another example of this type of stairs in the cathedral of Plasencia. To ascend to the organ or melon, there is a spiral staircase of reduced dimensions $1177 \mathrm{~cm}$ in diameter), crowned by a spherical dome joined with only one helicoidal course, that was found out by Professor Enrique Rabasa. We have no evidence of the authorship of this stair (Figure 5). In Plasencia worked,

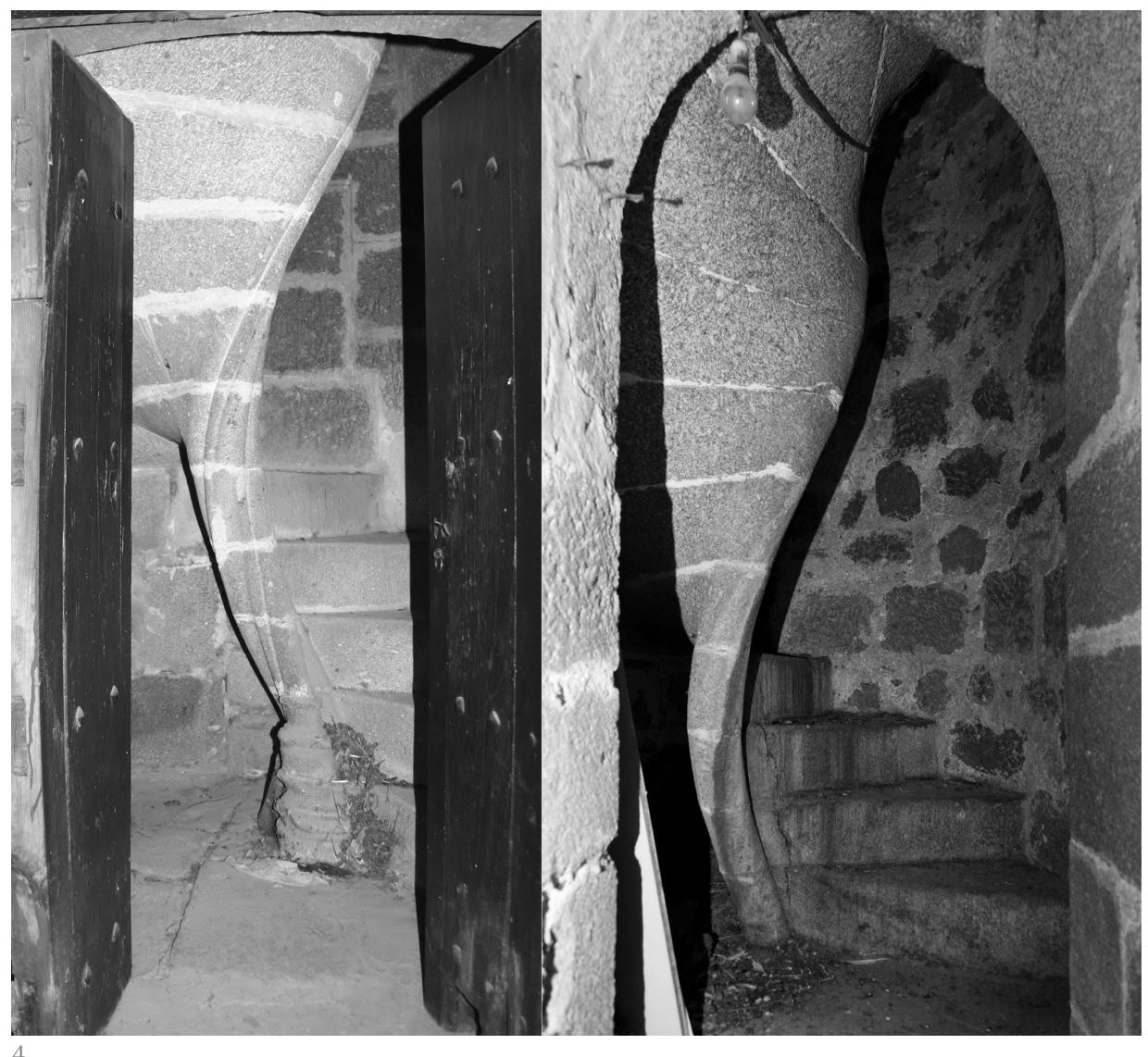


el remate de la bóveda baída que cubre una impresionante escalera de tramos rectos adyacente a la iglesia jerónima de Talavera por la que se sube para llegar al caracol de machón helicoidal. Por lo tanto nos enfrentamos a un complejo escenario en el que se muestran caracoles y bóvedas de especial singularidad con la intervención de actores como Alonso de Covarrubias, Rodrigo Gil de Hontañón o Pedro de Tolosa.

En la catedral de Sevilla también encontramos un caracol de este tipo. Se trata del que permite el acceso desde las terrazas de las naves laterales a la actual Capilla Real. Es una pieza vinculada a la fábrica gótica, con la que mantiene hiladas y trabas de aparejo, molduras y remate $(5$, p.291).



Para el profesor Pinto puede ser una solución de transición entre el husillo gótico y el Caracol de Mallorca, ya plenamente vigente a lo largo del siglo XVI en toda la Península. Una teoría por la cual se estaría intentando fijar un modelo todavía desconocido, importado del ámbito mediterráneo. Si bien es cierto que el caracol de Sevilla pudo ser el primero de este tipo, creo que hay que desechar esa posibilidad, pues el resto de caracoles de la serie se construyen en pleno siglo XVI. Sin ir más lejos, en la iglesia de Santiago Apóstol encontramos un Caracol de Mallorca, de no muy buena factura, en el primer tramo de la escalera, y un caracol de este nuevo tipo en el tercer tramo. Es decir, el autor del tercer tramo forzosamente tuvo que conocer este tipo de caracoles de ojo. Estos ejemplos se construyen en iglesias donde trabajan maestros de primer nivel, que ya estaban ejecutando espléndidos ejemplares de caracoles de ojo. No parece, por tanto, que sean experimentos, sino una manera especial de resolver un caracol con ojo en muy poco espacio. Estaríamos ante la creación de un nuevo tipo de caracol, de autor, que finalmente sucumbió ante el Caracol de Mallorca, que se convertirá en el más característico de la arquitectura hispana. among others, Alonso de Covarrubias, who also designed the church in the Jerome convent of Talavera de la Reina, and Rodrigo Gil de Hontañón. There is another spherical cap of this type, with helicoidal joining, at the crown of a spiral stair with stairwell in the Palacio de los Guzmanes in Leon, another building from Rodrigo Gil. As another piece of this jigsaw puzzle of sites, authors and constructive elements, we find a small dome with helicoidal joining at the crown of the sail vault over a spectacular straight flights stair next to the Jerome church of Talavera, that leads to the spiral staircase with helicoidal buttress. Therefore we are facing a complex scenario that shows spiral stairs and vaults of extraordinary singularity with the intervention of actors such as Alonso de Covarrubias, Rodrigo Gil de Hontañón or Pedro de Tolosa.

In Seville's cathedral, another spiral staircase of this type is to be found in the stair that gives access to the actual Royal Chapel from the terraces of the side aisles. This construction element is linked to the Gothic masonry through the courses and joined masonry, moldings and crowning (5, p. 291).

According to Professor Pinto, this solution could correspond to the transition between the Gothic spiral staircase with newel and the Caracol de Mallorca, very common during the $16^{\text {th }}$ century in the whole Peninsula. This theory would intend to fix a still unknown model imported from the Mediterranean area. Although the spiral staircase from Seville could have well been the first one of this type, I think we should reject this possibility, because all the other spiral staircases from this series were constructed in the $16^{\text {th }}$ century. Also in the church of Santiago Apóstol, in the first flight of the stair, we find a Caracol de Mallorca, that shows a rough work, and, in the third flight of the stair, a spiral staircase of this type. That is to say, the author of the third flight must have necessarily known this type of spiral staircases with well. These examples were constructed in churches in which first level masters participated, that were already executing splendid examples of well-staircases. It doesn't seem, therefore, that they were experimentations, but a special manner to solve a well spiral staircase in a reduced space. We would be in front of the creation of a new type of spiral staircase, by an author, that would culminate with the Caracol de Mallorca, the most characteristic one of the Hispanic architecture.
5. Escalera de caracol de subida al órgano de la catedral de Plasencia. Fotografía del autor.

5. Spiral staircase to the organ of the Cathedral of Plasencia. Photography by author. 
6. Bóveda helicoidal de generatriz circular horizontal en la escalera de subida al cupulín de la torre de la iglesia Mayor de Medina Sidonia. Fotografía del autor.

6. Helicoidal vault with horizontal circular ruling in the stair to the dome of the tower of the church in Medina Sidonia. Photography by author.

7. Bóveda helicoidal de generatriz circular horizontal en la escalera de la torre oriental del transepto de la catedral de Beauvais. Fotografía del autor.

Helicoidal vault with horizontal circular ruling in the stair of the easter tower of the transept in Beauvais' cathedral. Photography by author.

\section{CARACOLES ABOVEDADOS DE GENERATRIZ CIRCULAR HORIZONTAL}

Otro tipo singular de escaleras de trazado curvo, no recogidas en los manuscritos y tratados de cantería, está constituido por un grupo de escaleras vinculadas a la figura del maestro jerezano Francisco Rodríguez Cumplido. Estas escaleras abovedas se caracterizan porque la bóveda se genera por el giro helicoidal de una circunferencia horizontal. Conocemos, hasta ahora, la escalera de la torre de la iglesia Mayor de Medina Sidonia y la de subida a las cubiertas en la iglesia del convento de Santo Domingo de Guzmán en Sanlúcar de Barrameda, ambas en la provincia de Cádiz y vinculadas sin ninguna duda a Francisco Rodríguez. Existe un tercer ejemplar situado en uno de los cubos que enmarcan la Puerta de las Cadenas en la fachada septentrional del transepto de la catedral de Málaga. En estos tres casos el diseño de la escalera forma un ojo en el eje del cilindro contenedor. Han sido descritas y estudiadas con anterioridad (8) y nos detendremos en un pequeño ejemplar que sube del cuerpo de campanas a la sala inferior del cupulín de la torre de la Iglesia de Santa María la Mayor en Medina Sidonia, que tiene un antecedente en la torre oriental del transepto de la catedral de Beauvais en Francia (9) (Figuras 6 y 7). En ambas encontramos una solución similar a los tres casos andaluces, pero están resueltas con un machón central, como si fueran husillos que soportan una bóveda achatada, como las descritas anteriormente. Tanto en Medina Sidonia como en Beauvais se llega a una solución casi idéntica, sin que haya ninguna razón evidente de esa posible relación. Resulta especialmente reseñable el ejemplo francés, pues en un mismo tiro de escalera se suceden distintas soluciones, todas de una complejidad extrema, como si se estuviera buscando un diseño especial o se estuviera examinando la pericia de diferentes profesionales. Volvemos a encontrar ejemplos de escaleras con una solución muy compleja ubicadas en lugares de muy difícil acceso y con una función exclusivamente de mantenimiento del edificio.

\section{VAULTED SPIRAL STAIRCASES WITH HORIZONTAL CIRCULAR RULING}

Another singular type of stairs on circular plan, not acknowledged by the stonework manuscripts and treatises, is the one constituted by a group of stairs linked to the figure of the master from Jerez, Francisco Rodríguez Cumplido. These staircases are characterized by a vault which is generated by the helicoidal rotation of a horizontal circumference. We know already about the stair in the tower of the church of Medina Sidonia and the stair that rises to the roofs of the convent church in Santo Domingo de Guzmán in Sanlúcar de Barrameda, both in the province of Cádiz and undoubtedly linked to Francisco Rodríguez. There is a third example located in one of the cylinders flanking the Puerta de las Cadenas in the north façade of the transept in the cathedral of Málaga. In these three cases the design of the stair forms a well in the axis of the circumscribed cylinder. They have already been described and studied (8) and we will focus on a small example that rises from the bell section to the lower room of the small dome of the tower in the church of Santa María la Mayor in Medina Sidonia, that has a precedent in the Easter tower of the transept in Beauvais' cathedral in France (9) (Figures 6, 7). Both cases show a similar solution to that of the three Andalusian ones, but they have a central buttress, as they would have been spiral staircases with central newel supporting a quite flat vault, as those described before. Both are solved in a similar way, but no reason has been found for this relationship. The French example is especially outstanding, because in the same flight of the stair we can find different solutions, all of them of an extreme complexity, as if a search for a special design or a kind of demonstration of the mastery of different professionals would have taken place. Again, examples of stairs with very complex solutions are located in places of very difficult access and with a service function or maintenance use.

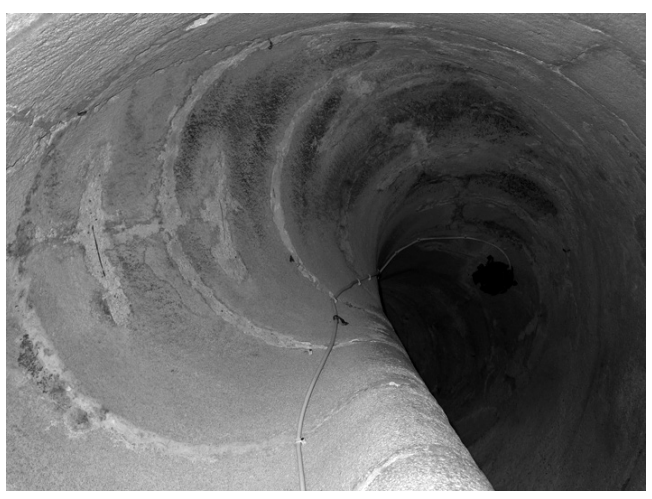

6

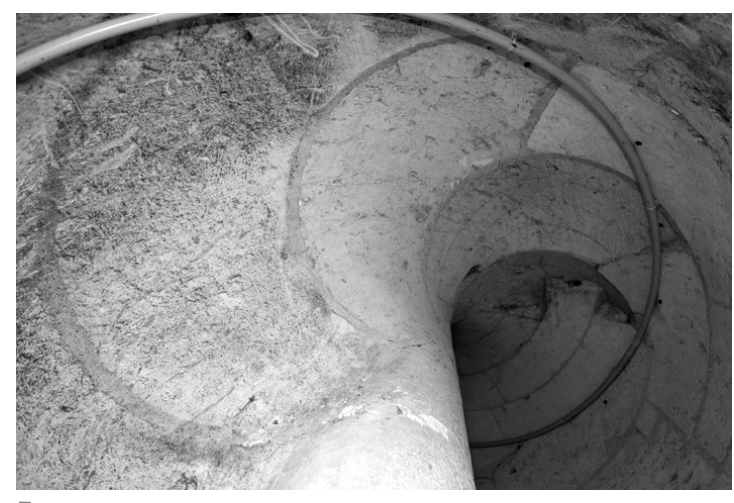

7 


\section{EJEMPLOS SINGULARES EN LOS MANUSCRITOS Y TRATADOS DE CANTERÍA}

Los tratados y manuscritos de cantería recogen numerosos tipos de caracoles que prácticamente no se llegaron a ejecutar $\mathrm{o}$, si lo hicieron, fue en muy contadas ocasiones. En algunos casos estos modelos aparecieron en manuscritos y tratados muy vinculados a la práctica constructiva y se trasladaron a los grandes tratados de estereotomía del siglo XVIII, como el de La Rue o Frezier.

Un buen ejemplo de esto lo podemos apreciar en la vis de Saint Gilles quarrée o Caracol de Emperadores Cuadrado. Se trata de un caracol abovedado de planta cuadrada. Aparece en los manuscritos hispanos de Alonso de Vandelvira y Hernán Ruiz y en los tratados impresos de Philibert de L'Orme, Mathurin Jousse, Francois Derand, Milliet Dechales, De La Rue, Frezier, etc. (Figura 8). A pesar de su amplísima difusión escrita, solo conocemos una referencia de una escalera de este tipo construida. D'Aviler, en su diccionario de arquitectura, cita las pequeñas escaleras del Palacio de Luxemburgo en Paris, hoy desaparecidas, como modelo construido de este tipo. Rondelet nos da alguna pista de su escasa utilización e incluso llega a desaconsejar su uso al ser muy dificultosa su construcción, y pone de relieve su escasa utilidad frente a un caracol de traza circular y el aspecto poco agradable de su intradós (10).

¿Por qué entonces aparece en tantos tratados? Una razón sería otorgar a determinadas trazas un valor especial, diferenciador, que también da prestigio a quien es capaz de diseñarla. Es evidente que la vis de Saint Gilles en su versión circular ostentó tal cualidad. El propio De L'Orme lo cita en su explicación del modelo (11) y no hay más que echar un vistazo a los muros que delimitan el modelo original en Saint Gilles para descubrir la admiración que despertaba tal escalera entre los canteros. Pensamos que la Vis de Saint Gilles Quarrée es otro ejemplo de esto mismo.

Nos podríamos preguntar asimismo por la razón de que en los documentos manuscritos de maestros canteros y arquitectos de los siglos XVI, XVII y XVIII encontremos cortes de cantería entre los que se encuentran complejos caracoles que nunca se llegaron a ejecutar. Bonet Correa expone la tesis de que la finalidad de estas cartillas o colecciones de aparejos era la transmisión de la experiencia constructiva y el oficio. Estaban, según él, dirigidas a aprendices, y

\section{SINGULAR EXAMPLES IN STONECUTTING TREATISES AND MANUSCRIPTS}

Stonecutting treatises and manuscripts include numerous types of spiral staircases that were not put into practice or, if so, only in very few occasions. In some cases, these models appeared in manuscripts and treatises linked to the constructive practice and were transferred to the great stereotomy treatises from the $18^{\text {th }}$ century, such as those of De La Rue or Frezier.

The vis de Saint Gilles quarrée or Caracol de Emperadores Cuadrado is a good example of this. It refers to a vaulted spiral staircase on square plan, that appears in the Spanish manuscripts of Alonso de Vandelvira and Hernán Ruiz and in the printed treatises from Phillibert de L'Orme, Mathurin Jousse, Francois Derand, Milliet Dechales, De La Rue, Frezier, etc. (Figure 8). Despite its widespread diffusion in texts, we only know of one example of a spiral staircase of this type implemented in practice. D'Avilier, in his dictionary of architecture, mentions the small staircases in the Palace of Luxemburg in Paris, today disappeared, as constructed model for this type. Rondelet gives us some clues of their scarce use and he even advises against its employment due to the difficulties of construction, highlighting its short use in comparison to the spiral staircase on circular plan, and the somewhat unpleasant appearance of its intrados surface (10).

What motivated this model to be included in so many treatises? A possible reason would be to add a special differencing value to some layouts, as was the case of this specific stair, giving at the same time prestige to the master capable to design it. There is no doubt that the circular vis de Saint Gilles held this attribute. De L'Orme himself mentions it in his explanation of the model (11) and just taking a look at the surface of the walls delimiting the original model in Saint Gilles one can discover the admiration that stonemasons felt for such stair. We believe that the Vis de Saint Gilles Quarrée is another example of this.

In addition, we could also ask ourselves for the reason why between the stonecuttings found in the manuscripts of stonemasons and architects from the $16^{\text {th }}, 17^{\text {th }}$ and $18^{\text {th }}$ centuries, there are complicated spiral staircases that were never taken into practice. Bonet Correa maintains that the objective of these collections of stonework bondings or cartillas was the transmission of the constructive experience and the profession to the apprentices. They
8. Vis de Saint Gilles quarrée en el Traité de la coupe des pierres de Jean Baptiste de La Rue. 1728 p.141.

8. Vis de Saint Gilles quarrée in Traité de la coupe des pierres of Jean Baptiste de La Rue. 1728. p. 141

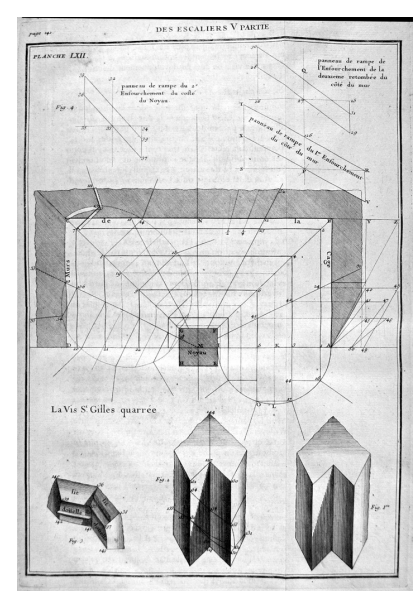


se prestaban de mano en mano sin salir del estricto círculo gremial (12).

Por otra parte, parece demostrado que el diseño de trazas singulares y complejas era un activo que podría poner de manifiesto la destreza de un profesional en el momento de optar a un trabajo de cierta relevancia. Los profesionales guardarían un auténtico portfolio o álbum donde se mostrarían sus más preciados cortes de cantería, algunos fruto de la transmisión dentro de los talleres y otros del diseño propio, y entre ellos se encontraban con frecuencia las escaleras de caracol.

Estas colecciones, en algunos casos, tenían un espíritu casi enciclopédico, donde podíamos encontrar todo tipo de modelos y variantes de un mismo elemento constructivo.

A veces, estas trazas fueron concebidas para ser presentadas en concursos de oposición. Fernando Marías rescata el memorial de oposición del maestro de arquitectura Pedro de Ávila Cenicientos, de 1685, para la provisión de la plaza de maestro mayor de las obras reales. En él, para cumplir con las pruebas exigidas, el maestro Pedro de Ávila presentaba "seis modelos de cortes de cantería de los más selectos, como es un cielo raso, un capialzado, un arco a dintel por esquina, un arco de viaje contra viaje, un arco de bajada de escalera y una vuelta por tranquil" y al mismo tiempo añadía el compromiso de hacer otros muchos cortes de cantería todavía "más exquisitos". Marías recoge asimismo las propuestas de otros aspirantes en términos similares. Incluso uno de ellos llega a afirmar que tenía concluidos, y podría presentarlos, dos "cortes y las trazas y monteas de ellos"; afirmó que era ésta "la materia más dificultosa que se ofrece en las fábricas y lo que deben saber los maestros por ser la cantería de lo que se han fabricado todas las obras más insignes" $(13$, p. 351) (14, p.93).

Las escaleras de caracol formaron parte inequívoca de estos "cortes exquisitos". Juan de Portor (1679-17??), al describir el caracol volado de ojo redondo en una planta cuadrada, uno de sus modelos de caracoles más singulares, escribe:

"Con esta planta daremos fin a los caracoles de este género que te prometo es una traza esta de estos caracoles muy grave que por lo menos yo estoy muy pagado que aunque no traza que se ofreciera muchas veces ocasión para ejecutarla es traza para valerse de ella en una oposición como ya ha sucedido porque fue una de las trazas que valieron a un were, according to him, addressed to the apprentices, and they were shared by them without leaving the close guild circle of the trade (12).

Furthermore, there is some evidence that the design of singular and complicated layouts was an asset that could highlight the skills of a mason aiming for a position of special relevance. The professionals would keep a genuine portfolio or album to show their most appreciated stonecuttings, some of them being the result of the transmission within the workshops and others, the product of their own design, and among them there were frequently the spiral staircases.

These collections, in some cases, had nearly an encyclopedic character, where every type of models and different options for the same constructive element could be found.

In some cases, these designs where conceived to be presented in public competitive examinations. Fernando Marías recalls the report of the competitive examination from the master mason Pedro de Ávila Cenicientos, in 1685, to cover the position of master mason for the Crown construction works. To fulfill the required test, the master Pedro de Ávila presented "seis modelos de cortes de cantería de los más selectos, como es un cielo raso, a capialzado, un arco a dintel por esquina, un arco de viaje contraviaje, un arco de bajada de escalera y una vuelta por tranquil" adding, at the same time, the compromise to perform many other stonecutting models, even more complex ones. Marías recalls also the proposals of some other candidates in similar terms. Even one of them affirms that he had concluded, and could present, "dos cortes y las trazas y monteas de ellos"; he stated that this was "la materia más dificultosa que se ofrece en las fábricas y lo que deben saber los maestros por ser la cantería de lo que se han fabricado todas las obras más insignes" (13, p. 351) (14, p. 93).

Spiral stairs were undoubtedly part of these refined stonecuttings. Juan de Portor (169717??), describing the flying spiral staircase with circular well on square plan, one of his most singular spiral staircases, writes:

"Con esta planta daremos fin a los caracoles de este género que te prometo es una traza esta de estos caracoles muy grave que por lo menos yo estoy muy pagado que aunque no traza que se ofreciera muchas veces ocasión para ejecutarla es traza para valerse de ella en una oposición como ya ha 
maestro mayor en la Iglesia de Granada Martínez de Aranda Salazar en la oposición que tuvo con el maestro Bartolomé de Lechuga en dicha Iglesia de Granada $=\mathrm{Y}$ ahora te suplico por amor de Dios que me encomiendes muy de veras a su divina majestad que Dios te lo premiará en pago del trabajo que puedes considerar que esto me costó el ponerlo en la forma que ves = Deus Supernominial."

Precisamente a este tipo de objetivo podrían responder los diseños que para los caracoles exentos o volados proponen Martínez de Aranda y Juan de Portor y Castro en sus respectivos manuscritos.

Martínez de Aranda presenta el caracol exento alrededor de un macho redondo capialzado en circunferencia y su versión de dos subidas. Si el caracol exento contiene una especial complejidad en su diseño, el caracol de dos subidas añade la originalidad de concebir un doble caracol volado alrededor de una columna circular (Figura 9) (M1). Este modelo pudo influir en Portor y Castro en estas cinco trazas: caracol volado en una planta redonda, caracol volado en una caja redonda, caracol volado alrededor de una pilastra, caracol volado en una caja cuadrada y el caracol volado de ojo redondo en una planta cuadrada (M2).



El estudio de estas trazas nos ha permitido confirmar la teoría, iniciada por el profesor Calvo López, de una relación directa entre el manuscrito de Martínez de Aranda y el de Portor y Castro (15, p.133). Por lo que sabemos hasta ahora, Portor y Castro, de origen santiagués, desarrolló su actividad profesional entre Santiago y Granada. Martínez de Aranda, nacido en Baeza, acompañó a Maximiliano de Austria hasta Santiago de Compostela al ser nombrado arzobispo de su diócesis, y ostentó el cargo de maestro de obras de la catedral entre 1603 y 1608. Le sucedió Bartolomé Fernández Lechuga citado junto a Juan de Aranda Salazar por Portor, precisamente en una de estas trazas, en su Cuaderno de Arquitectura. En alguno de estos lugares Juan de Portor debió de entrar en contacto con el manuscrito de Martínez de Aranda. El caracol volado sucedido porque fue una de las trazas que valieron a un maestro mayor en la Iglesia de Granada Martínez de Aranda Salazar en la oposición que tuvo con el maestro Bartolomé de Lechuga en dicha Iglesia de Granada $=Y$ ahora te suplico por amor de Dios que me encomiendes muy de veras a su divina majestad que Dios te lo premiará en pago del trabajo que puedes considerar que esto me costó el ponerlo en la forma que ves = Deus Supernominial."

This kind of objective could give an answer to the designs that were proposed by Martínez de Aranda and Juan de Portor y Castro in their corresponding manuscripts for the free-standing or for the flying spiral staircases.

Martínez de Aranda presents the caracol exento alrededor de un macho redondo capialzado en circunferencia (free-standing spiral stair around a circular newel raised on a circumference) and its double version. To the free-standing spiral staircase special complexity, the double free-standing spiral staircase provides the originality of a cantilevered double spiral stair around a circular column (Figure 9) (M1). This model could have had some influence on Portor $y$ Castro in these five layouts: caracol volado en una planta redonda, caracol volado en una caja redonda, caracol volado alrededor de una pilastra, caracol volado en una caja cuadrada y el caracol volado de ojo redondo en una planta cuadrada (M2).

The analysis of these layouts has allowed us to confirm the theory, initiated by professor Calvo López, of a direct relation between the manuscripts of Martínez de Aranda and that one of Portor y Castro $(15,133)$. According what we know now, Portor y Castro, born in Santiago de Compostela, developed his professional activity between Santiago and Granada. Martínez de Aranda, born in Baeza, accompanied Maximiliano de Austria to Santiago de Compostela when he was appointed archbishop of his diocese, and was responsible for the master mason of the cathedral between 1603 and 1608. He was succeeded by Bartolomé Fernández Lechuga, cited together with Juan de Aranda Salazar by Portor, just in one of these layouts, in his Cuaderno de Arquitectura. Juan de Portor must have known about the manuscript of Martínez de Aranda on some of these places. The flying spiral staircase on circular plan is very similar to the free-standing spiral staircase around a circular newel, raised on a circumference from Aranda (Figure 10). Both authors employ a different term for the stonecutting, but the step piece is very similar with the differences derived
9. Izquierda. Caracol exento alrededor de un macho redondo capialzado en circunferencia de dos subidas en el manuscrito $\mathrm{Ce}$ rramientos y trazas de montea de Ginés Martínez de Aranda. Derecha. Restitución del caracol. Infografía del autor.

9. Left. Free-standing double spiral staircase around a circular newel, raised on a circumference, in the manuscript Cerramientos y trazas de montea of Ginés Martínez de Aranda. Right. Restitution. Infography by author. 
10. Izquierda. Caracol exento alrededor de un macho redondo capialzado en circunferencia de Ginés Martínez de Aranda. Derecha. Caracol volado en una planta redonda de Juan de Portor y Castro.

10. Left. Free-standing spiral staircase around a circular newel, raised on a circumference of Ginés Martínez de Aranda. Right. Flying spiral stair on circular plan of Juan de Portor y Castro.

11. Comparación gráfica entre el peldaño del caracol volado en una planta redonda de Juan de Portor y Castro (izquierda) y el peldaño del caracol exento alrededor de un macho redondo capialzado en circunferencia de Ginés Martínez de Aranda (derecha). Dibujo del autor.

11. Graphical comparison between the step of the flying spiral stair on circular plan of Juan de Portor y Castro (left) and the step of the free-standing spiral staircase around a circular newel, raised on a circumference of $\mathrm{Gi}^{-}$ nés Martínez de Aranda (right). Drawing by author.

12. Izquierda. Declaración del caracol exento en el manuscrito de Vandelvira. Derecha. Restitución del caracol. Infografía del autor.

12. Left. Declaración del caracol exento in Vandelvira's manuscript. Right. Restitution. Infography by author.

13. Engatillado en la pieza de peldaño de la escalera de subida al púlpito de la iglesia del convento de Santo Domingo de Bonaval en Santiago de Compostela. Fotografía del autor.

13. Cogging on a step piece, stair to the pulpit in the church of the convent of Santo Domingo de Bonaval in Santiago de Compostela. en una planta redonda es muy similar al caracol exento alrededor de un macho redondo capialzado en circunferencia de Aranda (Figura 10). Ambos autores utilizan una denominación diferente para el corte, pero la pieza de peldaño es prácticamente igual con las diferencias derivadas fundamentalmente de la distinta dimensión del machón central de empotramiento de la escalera (Figura 11). Aranda propone un machón central más estrecho con 16 peldaños por giro. Portor presenta un machón de grandes dimensiones lo que provoca que el giro se complete con 23 peldaños. Aranda, por ejemplo, denomina a la sección transversal curva de cada peldaño circunferencia arbotante, mientras que Portor la denomina capialzo, debido sin duda a que el extremo libre del peldaño se encuentra elevado con respecto al inicio del arco, cerca del machón de empotramiento. Ambos conforman la tirantez a base de una línea paralela en contraposición a Vandelvira, que en su Declaración del caracol exento la propone radial (Figura 12) (M3). El engatillado es mucho más sofisticado en los casos de Portor y Aranda que en el de Vandelvira, más sencillo. El sistema de engatillado de los peldaños ha sido muy utilizado en Francia, donde encontramos numerosos ejemplos construidos, pero muy poco utilizado en España. Podemos citar el ejemplo del caracol volado alrededor de un pilar, para subir al púlpito, en la iglesia de Santo Domingo de Bonaval en Santiago de Compostela (Figura 13).

Portor elabora todo un catálogo de situaciones diferentes partiendo de un mismo concepto. Peldaño volado que se empotra en un machón interior o exterior y que se apoya sobre el peldaño precedente por medio de un complejo engatillado. La pieza que sirve para ir desarrollando el catálogo de caracoles deriva de forma evidente de la que diseña Martínez de Aranda para este tipo de caracoles (Figuras 14 y 15).



basically from the different dimension of the central buttress of the fixed end of the stair (Figure 11). Aranda propounds a narrower central buttress with sixteen steps per turn. Portor shows a larger buttress, and 23 steps per turn as a consequence. Aranda, for example, refers to the curve cross section of each step as circunferencia arbotante, while Portor refers to it as capialzo, due, without a doubt, to the fact that the free end of the step is elevated in relation to the springing of the arch, near the fixed-end buttress. Both define the tirantez based on a parallel line in opposition to Vandelvira, who, in his Declaración del caracol exento, propounds it to be radial (Figure 12) (M3). The cogging is much more sophisticated in the proposals of Portor and Aranda that in the one offered by Vandelvira, which is simpler. The cogging of the steps has been employed frequently in France, where a great number of built examples can be found, but scarcely in Spain. We can cite the example of the flying spiral stair around a column, to climb up to the pulpit, in the church of Santo Domingo de Bonaval in Santiago de Compostela (Figure 13).

Portor develops a complete catalogue of different options from the same concept. A flying step with fixed connection to the inner buttress or the exterior wall and resting in the previous step by means of



10

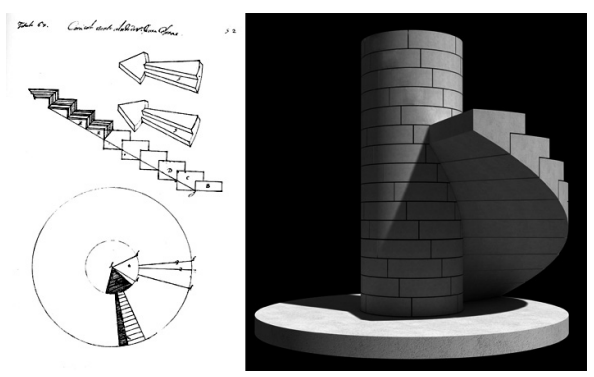

12

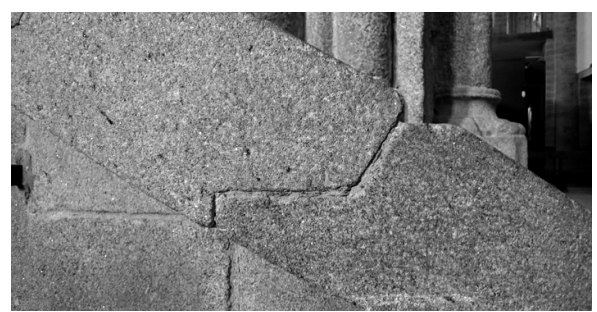

13 

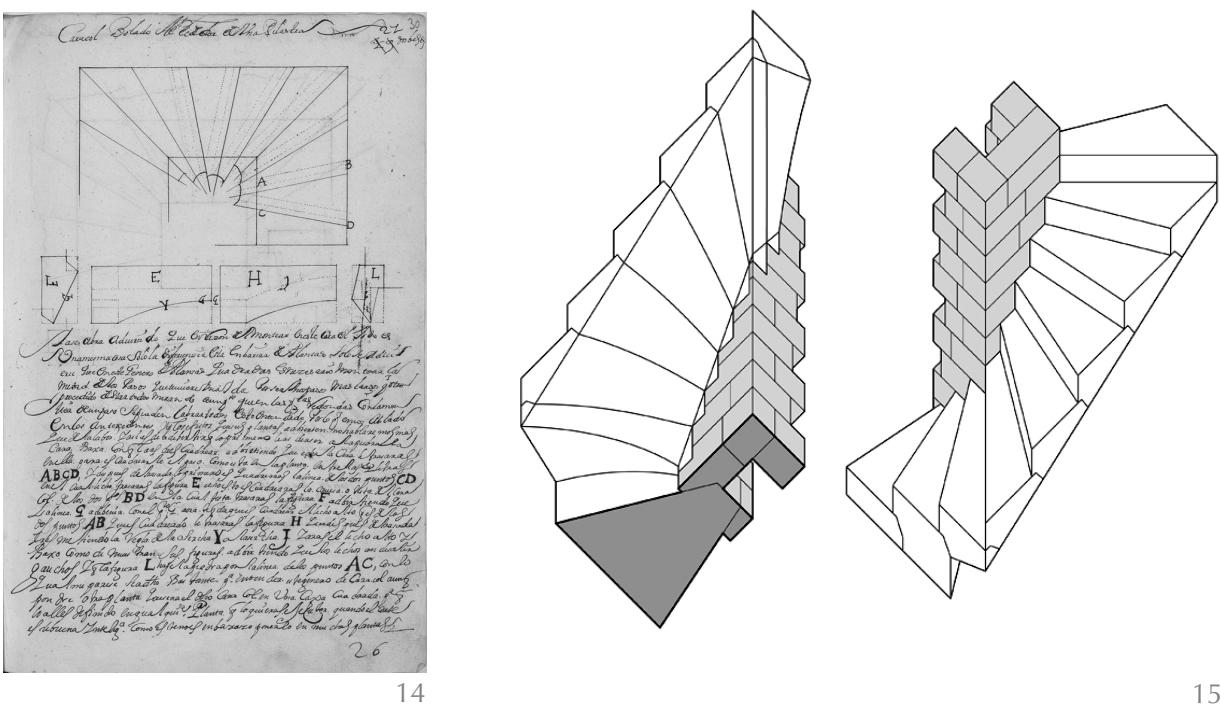

Esta voluntad de recoger casi enciclopédicamente cada tipo de caracol volado también deriva del carácter del manuscrito de Cerramientos y trazas de montea de Martínez de Aranda (15, p. 127).

\section{CONCLUSIONES}

Las escaleras de caracol han formado parte de un privilegiado grupo de elementos constructivos en constante evolución e investigación a lo largo de la historia de la arquitectura en piedra. Desde el cantero más humilde hasta los grandes maestros catedralicios las construyeron $y$, en muchos casos, crearon modelos nuevos en papel o en piedra. Estos modelos casi experimentales sirvieron para encontrar trabajo o demostrar un grado de profesionalidad a sus autores, que les hiciera, al mismo tiempo, ganarse el respeto de sus compañeros. Gracias a esto, se inició ese proceso de investigación y evolución que produjo una diversidad en los tipos, sin precedentes en otros elementos similares, y la transferencia de procedimientos dentro del arte de la cantería. Los grandes autores del mundo de la piedra propusieron multitud de tipos y variantes, sin embargo, el modelo de estereotomía tradicionalmente considerado más complejo y más admirado es un caracol de reducidas dimensiones construido en el siglo XII: la Vis de Saint Gilles.

Posiblemente ahí es donde reside la grandeza de este arte.

\section{AGRADECIMIENTOS}

El presente artículo está realizado en el marco del proyecto de investigación: Cons- a complex cogging. The piece used to develop the catalogue of spiral staircases derives evidently from that designed by Martínez de Aranda for this kind of spiral stairs (Figures 14 and 15).

This aim to thoroughly compile every type of flying spiral stair also derives from the character of the manuscript of Martínez de Aranda Cerramientos y trazas de montea $(15$, p. 127).

\section{CONCLUSIONS}

Spiral staircases have been part of a privileged group of constructive elements in constant evolution and research throughout the history of architecture in stone. They were built by the most modest stonemason to the great master masons of the cathedrals and, in most cases, they created new models on paper or in stone. These almost experimental models were useful to find a position or to demonstrate the professional skills of their authors, earning at the same time the respect of their colleagues. By virtue of this, a research process started, that has as a consequence a diversity of models without precedent in other similar constructive elements, and the transmission of proceedings in the art of stonecutting. The great authors in stone propounded a variety of prototypes, however the most admired and more complex model of stereotomy tradionally considered is a spiral staircase of reduced dimensions built in the $12^{\text {th }}$ century: the Vis de Saint Gilles.

Probably here is where the greatness of this art lies.

\section{ACKNOWLEDGEMENTS}

This paper has been developed in the context of the research project: "Stonecutting
14. Caracol volado alrededor de una pilastra en el manuscrito de Juan de Portor y Castro. 1708.

14. Flying spiral staircase around a column in the manuscript of Juan de Portor y Castro. 1708.

15. Restitución gráfica del caracol volado alrededor de una pilastra en el manuscrito de Juan de Portor y Castro. Dibujo de autor.

15. Graphical restitution of the flying spiral staircase around a column in the manuscript of Juan de Portor y Castro. Drawing by author. 
trucción en piedra de cantería en los ámbitos mediterráneo y atlántico. Análisis de ejemplos construidos. (BIA 2009-14350) financiado por el Ministerio de Ciencia e Innovación. Agradezco a la profesora Elena Pliego de Andrés por su trabajo de traducción de este artículo y a la profesora Isabel Salto-Weis por la revisión meticulosa de la traducción. technology in the Mediterranean and Atlantic areas. Survey and analysis of built examples (BIA 2009-14350)", sponsored by the Ministry of Science and Innovation of the Spanish Government. I wish to thank Elena Pliego de Andrés for translating this paper and Isabel Salto Weiss for checking the translation.

\section{REFERENCIAS / REFERENCES}

(1) Sanjurjo, A. (2009). Historia y construcción de la escalera de caracol: el baile de la piedra, en El arte de la piedra. Teoría y práctica de la cantería: 233-257. Madrid. Ceu Ediciones.

(2) Vergnolle, E. (1989). Passages muraux et escaliers: premières expériences dans I'architecture de $\mathrm{XI}^{\mathrm{e}}$ siècle en Cahiers de civilisation médiévale, XXXIIe Année, $\mathrm{n}^{\circ}{ }^{1}$, JanvierMars 1989: 43-60. Université de Poitiers.

(3) Villes, A. (2006). La Modernisation de la cathédrale Saint-Etienne de Sens aux XIII et XIV siècles en Bulletin de la Société Archéologique de Sens. Études nouvelles sur la cathédrale de Sens. Tome V: 115-171.

(4) Ruiz Hernando, J.A. (2003). Las trazas de la catedral de Segovia, Diputación provincial de Segovia. Caja Segovia. Obra Social y Cultural.

(5) Pinto Puerto, F. (2006). Fábrica y forma del templo gótico en La catedral gótica de Sevilla. Fundación y fábrica de la obra nueva: 210-295. Universidad de Sevilla.

(6) Sanjurjo, A. (2010). La vis de Saint Gilles: analyse du modèle dans les traités de coupe des pierres et de son influence sur les traités espagnols de l'âge moderne, en Édifice\&Artifice. Histoires constructives: 679-689. Paris: Editions Picard.

(7) Gutiérrez Pulido, D. (2009). Pedro de Tolosa, maestro de cantería del siglo XVI, en la sierra de San Vicente (Toledo). Ayuntamiento de Talavera de la Reina.

(8) Pinto, F. y Sanjurjo, A. (2011). Francisco Rodríguez Cumplido. Soluciones singulares de cantería en la construcción de un lenguaje moderno en Actas del Séptimo Congreso Nacional de Historia de la Construcción: 1099-1108. Santiago de Compostela. Instituto Juan de Herrera.

(9) Sanjurjo, A. (2012). The Chambiges and the Construction of vaulted Stone Spiral Staircases en Nuts \& Bolts of Construction History. Culture, Technology and Society. Vol. 3: 67-74. Editions Picard. Paris.

(10) Sanjurjo, A. (2006). The vis Saint Gilles quarré or the caracol de emperador escuadrado: a model frequently encountered in Spanish-french architectural treatises from the Modern Period en Proceedings of the II International Congress on Construction History, The Construction History Society, Cambridge.

(11) L'Orme, Philibert de. (1567). Le premier tome de l'Architecture, París, Federic Morel.

(12) Bonet Correa, A. (1989). Los tratados de montea y cortes de piedra españoles en los siglos XVI, XVII y XVIII, Academia, 69, $2^{\circ}$ sem: 29-62.

(13) Marías Franco, F. (1993). Trazas, trazas, trazas: tipos y funciones del dibujo arquitectónico en Juan de Herrera y su influencia. Actas del Simposio. Camargo, 14 /17 julio de 1992: 351-359. Santander. Fundación obra pía Juan de Herrera-Universidad de Cantabria.

(14) Marías Franco, F. (1999). Elocuencia y laconismo: la arquitectura barroca española y sus historias en Figuras e imágenes del Barroco. Estudios sobre el barroco español y sobre la obra de Alonso Cano: 87-112. Colección Debates sobre Arte. Visor. Madrid.

(15) Calvo López, J. (2009) La literatura de la cantería: una visión sintética en El arte de la piedra. Teoría y práctica de la cantería, 101-156. Madrid: Ceu Ediciones.

\section{MANUSCRITOS / MANUSCRIPTS}

(M1) Martínez de Aranda, Ginés. c 1600. Cerramientos y Trazas de Montea. Biblioteca del Servicio Histórico Militar (SHM).

(M2) Ms 9114, (c 1708). Conocido como Cuaderno de Arquitectura, atribuido a Juan de Portor y Castro. Biblioteca Nacional de España (BNE).

(M3) R31, (c 1580). Conocido como Libro de trazas de cortes de Piedras, atribuido a Alonso de Vandelvira. Escuela Técnica Superior de Arquitectura de Madrid (ETSAM) Biblioteca. 